Original Article

\title{
HYDROCARBON COMPOSITION OF BEESWAX (APIS MELLIFERA) COLLECTED \\ FROM LIGHT AND DARK COLOURED COMBS
}

\author{
Ewa Waś* \\ Teresa Szczęsna \\ Helena Rybak-Chmielewska \\ Research Institute of Horticulture, Apiculture Division, \\ Kazimierska 2, 24-100 Puławy, Poland \\ *corresponding author: ewa.was@inhort.pl \\ Received 21 October 2014; accepted 17 November 2014
}

\section{Abstract}

The hydrocarbon composition of beeswax secreted by Apis mellifera was characterised. In the studies, analyses were made of virgin beeswax (obtained from light combs, socalled "wild-built combs") that was collected at different dates, and beeswax obtained from dark combs (,brood combs"). A qualitative analysis did not show any differences in the hydrocarbon composition of beeswax originating from light and dark coloured combs. The same hydrocarbons (n-alkanes, alkenes, and dienes) were identified in virgin beeswax and beeswax collected from brood combs. However, the studies showed differences in the content of $n$-alkanes in the beeswax obtained from light and dark coloured combs. In comparison to the virgin beeswax, the beeswax obtained from dark combs had higher content of the total n-alkanes, higher total contents of even-numbered alkanes and odd-numbered alkanes, and higher contents of certain alkanes. Furthermore, it has been found that the hydrocarbon composition of beeswax did not depend on the collection period.

Keywords: Apis melifera, beeswax, dark combs, hydrocarbons, light combs, n-alkanes.

\section{INTRODUCTION}

Hydrocarbons are natural compounds of beeswax. According to different authors, these aliphatic, long-chain compounds contain from 17 to 35 atoms of carbon (White et al., 1960; Downing et al., 1961; Aichholz and Lorbeer, 1999, 2000; Jimenez et al., 2004; Serra Bonvehi and Ornantes Bermejo, 2012; Maia and Nunes, 2013; Waś et al., 2014). Unbranched saturated hydrocarbons (n-alkanes) comprise about $67 \%$ of all the beeswax hydrocarbons. A considerably lower amount, about $2 \%$, include branched saturated hydrocarbons (iso-alkanes) and unsaturated hydrocarbons (alkenes). Alkenes occur mainly as the cis isomers (31.7\%). The trans isomers comprise only $0.2 \%$ (Streibl et al., 1966). Besides alkenes, beeswax also contains dienes - unsaturated hydrocarbons with two double bonds (Giumanini et al., 1995; Jimenez et al., 2004, 2006, 2007; Waś et al., 2014). The total content of hydrocarbons in beeswax determined by different authors, was between 12.3 to $17.8 \%$ (White et al., 1960; Aichholz and Lorbeer, 1999, 2000; Jimenez et al., 2006, 2007; Serra Bonvehi and Ornantes Bermejo, 2012). The content of n-alkanes (the most numerous group of beeswax hydrocarbons) determined by Waś et al. (2014) ranged from 9.08 to $10.86 \mathrm{~g} / 100 \mathrm{~g}$. Studies on the composition of the beeswax hydrocarbons conducted in the last few years (Aichholz and Lorbeer, 1999, 2000; Jimenez et al., 2004, 2006, 2007; Serra Bonvehi and Ornantes Bermejo, 2012; Maia and Nunes, 2013; Waś et al., 2014) confirmed the previous reports (White et al., 1960; Streibl et al., 1966) that among the n-alkanes, those containing odd numbers of carbon atoms in the molecules predominate, with high shares of $\mathrm{C}_{27} \mathrm{H}_{56^{\prime}} \mathrm{C}_{29} \mathrm{H}_{60^{\prime}} \mathrm{C}_{31} \mathrm{H}_{64^{\prime}}$ and $\mathrm{C}_{25} \mathrm{H}_{52}$.

Furthermore, the studies of Aichholtz and Lorbeer (1999, 2000) indicated that beeswax obtained from different species of the genus Apis differs in hydrocarbon content. Differences in the content of unsaturated hydrocarbons (alkenes and dienes) between the beeswax secreted by the African and European bees were noticed also by Carlson and 


\section{Hydrocarbon composition of Apis mellifera wax}

Bolton (1984), Beverly et al. (1995), and Giumanini et al. (1995).

The studies conducted in the 1950s by Curyło and Zalewski (1957) showed that beeswax obtained from light combs, in which no brood was yet present, contained less hydrocarbons (on average, 13.5\%), while beeswax obtained from old and dark coloured combs contained slightly more hydrocarbons (14.8 - 16.0\%). Differences in the content of hydrocarbons in beeswax obtained from light and dark combs were also observed by Tulloch and Hoffman (1972). Furthermore, Jimenez et al. (2007) and Namdar et al. (2007) determined a higher content of alkanes with even numbers of carbon atoms in the molecule, in beeswax obtained from dark combs.

Knowledge of the hydrocarbon composition of beeswax has proved to have a crucial meaning, mainly due to detection of this product's adulteration with much cheaper hydrocarbons of alien origin, e.g. paraffin which has a hydrocarbon composition and properties similar to beeswax. So far, the literature data considering hydrocarbon composition of beeswax, and especially those concerning quantitative analysis of these compounds, are incomplete. Such reports also lack any information on the hydrocarbon composition of beeswax obtained from light and dark coloured combs.

The aim of our studies was to characterise the hydrocarbon composition of beeswax originating from Apis mellifera and obtained from light and dark coloured combs.

\section{MATERIAL AND METHODS}

\section{Reagents}

Squalane (99.9\% purity) from Supelco (Bellefonte,PA, USA) was used as an internal standard. The analytical standard mixtures of n-alkanes $\left(\mathrm{C}_{8} \mathrm{H}_{18}-\mathrm{C}_{20} \mathrm{H}_{42}\right.$ in hexane and $\mathrm{C}_{21} \mathrm{H}_{44}-\mathrm{C}_{40} \mathrm{H}_{82}$ in toluene) were obtained from Fluka (Buchs, Switzerland; Saint Louis, MO, USA). Hexane SupraSolv ${ }^{\circledast}$ for gas chromatography ( $\geq 98 \%$ purity) was obtained from Merck (Darmstadt, Germany), and heptane anhydrous ( $\geq 98.5 \%$ purity) was from Sigma-Aldrich (Steinheim, Germany). Solidphase extraction (SPE) cartridges filled with neutral aluminum oxide (Alumina - N, $1000 \mathrm{mg}, 6 \mathrm{~mL}$ ) were purchased from Agela Technologies (Wilmington, DE, USA). Helium (99.9999\% purity) was provided by Air Products (Warsaw, Poland).

\section{Beeswax samples}

Beeswax samples originating from Apis mellifera were obtained from light coloured combs, so-called "wild-built combs" - the virgin beeswax ( $n=47)$, and from dark coloured combs (2-3 years old) - „brood combs" ( $n=23)$.

The virgin beeswax was collected from May - June of $2009(n=16)$, and from May - June $(n=20)$ and July $(n=11)$ of 2010 . Samples of the virgin beeswax originated from the apiaries belonging to the Department of Beekeeping Technology of the Research Institute of Horticulture, Apiculture Division in Puławy, Poland, and from a private apiary cooperating in the study, located in the vicinity of Puławy. The beeswax from dark combs was obtained from the organic apiary belonging to the Department of Beekeeping Technology, the Apiculture Division, Puławy. The combs were built on the organic foundation holding a certificate confirming its quality.

The beeswax combs were melted in a drying oven $\left(70-75^{\circ} \mathrm{C}\right.$ ) and purified on a filter made of gauze. Homogenised and free from mechanical impurities, the beeswax samples were kept in a dry, cool, dark place until further analysis.

\section{Sample preparation}

The beeswax sample $(0.05 \pm 0.001 \mathrm{~g})$ was diluted with $7.5 \mathrm{~mL}$ of heptane using an incubated shaker (in $50^{\circ} \mathrm{C}$ for $\left.12 \mathrm{~min}\right)$. After cooling the solution, $2.5 \mathrm{~mL}$ of squalane of $400 \mathrm{mg} / \mathrm{L}$ concentration was added and mixed. Then, hydrocarbon fraction was isolated using the SPE technique with cartridges filled with neutral aluminum oxide after elution with hexane (Waś et al., 2014).

\section{Analysis of beeswax hydrocarbons}

The determination of beeswax hydrocarbons was conducted as it was described previously (Waś et al., 2014). Analyses were carried out using gas chromatograph with mass detector (GCMS-QP 2010 Plus, Shimadzu). Chromatographic separation of hydrocarbons was performed on ZB-5HT INFERNO column (20 $\mathrm{m} \times 0.18 \mathrm{~mm} \times 0.18 \mu \mathrm{m}$, Phenomenex). Identification of studied compounds was done based on the mass spectra of the NIST 05 library and on the retention times. The quantitative analysis of n-alkanes was performed using squalane $\left(\mathrm{C}_{30} \mathrm{H}_{62}\right)$ as an internal standard. The recovery of the individual n-alkanes was from 94.4 to $105.9 \%$ and for the total n-alkanes it was $100.5 \%$. The limits of determination of the method defined for each alkane $\left(\mathrm{C}_{20} \mathrm{H}_{42}\right.$ $-\mathrm{C}_{35} \mathrm{H}_{72}$ ) were from 0.005 to $0.025 \mathrm{~g} / 100 \mathrm{~g}$ (Waś et al., 2014).

\section{Statistical analysis}

The results were statistically analysed with the STATISTICA 10 software. Due to the data distribution, the non-paramertical Mann-Whitney U test (sig- 
nificance level $\alpha=0.05$ ) was used for comparing the differences between the determined contents of n-alkanes in beeswax.

\section{RESULTS}

In the virgin beeswax (from light coloured combs, the so-called "wild-built combs"), obtained at different dates, long-chain n-alkanes containing from 20 to 35 carbon atoms in their molecule were found (Fig. 1). Beside the n-alkanes, the presence of unsaturated hydrocarbons - alkenes $\left(\mathrm{C}_{23} \mathrm{H}_{46^{\prime}} \mathrm{C}_{25} \mathrm{H}_{50^{\prime}} \mathrm{C}_{27} \mathrm{H}_{54^{\prime}} \mathrm{C}_{29} \mathrm{H}_{58^{\prime}}\right.$ $\left.\mathrm{C}_{31} \mathrm{H}_{62}, \mathrm{C}_{33} \mathrm{H}_{66^{\prime}} \mathrm{C}_{35} \mathrm{H}_{70}\right)$ and dienes $\left(\mathrm{C}_{31} \mathrm{H}_{60}, \mathrm{C}_{33} \mathrm{H}_{64^{\prime}}\right.$ $\left.\mathrm{C}_{35} \mathrm{H}_{68}\right)$ was also noted. For some alkenes $\left(\mathrm{C}_{23} \mathrm{H}_{46^{\prime}}\right.$ $\mathrm{C}_{25} \mathrm{H}_{50}, \mathrm{C}_{27} \mathrm{H}_{54^{\prime}}, \mathrm{C}_{31} \mathrm{H}_{62}, \mathrm{C}_{35} \mathrm{H}_{70}$ ), two isomers were found. The same hydrocarbons were identified in the beeswax obtained from the dark coloured combs (,brood combs").

The results indicate differences in composition of beeswax from light and dark combs related to the quantitative analysis of n-alkanes (the most numerous group of beeswax hydrocarbons). The total content of n-alkanes in the virgin beeswax ranged from 8.27 to $11.66 \mathrm{~g} / 100 \mathrm{~g}$ (on average, $9.50 \mathrm{~g} / 100 \mathrm{~g})$, and in the beeswax obtained from dark combs from 9.46 to $10.84 \mathrm{~g} / 100 \mathrm{~g}$, with an average of $10.22 \mathrm{~g} / 100 \mathrm{~g}$ (Tab. 1). The total content of n-alkanes with an odd number of carbon atoms in the molecule (hereafter called the odd-numbered alkanes), in the beeswax obtained from light and dark coloured combs was substantially higher in comparison to the content of n-alkanes with an even number of carbon atoms in the molecule (hereafter called the even-numbered alkanes). The average total content of odd-numbered n-alkanes amounted to 94.9 and $94.2 \%$ of all the n-alkanes found in beeswax obtained from light and dark coloured combs, respectively. The highest contents were determined for $\mathrm{C}_{27} \mathrm{H}_{56}, \mathrm{C}_{29} \mathrm{H}_{60}, \mathrm{C}_{31} \mathrm{H}_{64}$, and $\mathrm{C}_{25} \mathrm{H}_{52}$ with the average contents of these alkanes $34.0,23.5,20.3$, and $8.6 \%$, respectively, of the total content of unbranched alkanes determined in the virgin beeswax; and 34.5, 22.5, 18.4, and $10.1 \%$ of the total content of n-alkanes determined in the beeswax obtained from dark coloured combs.

The Mann-Whitney $U$ test showed statically significant differences for the total content of unbranched alkanes $\left(U_{47.23}=180.0, p=0.000\right)$, and for the total content of even-numbered alkanes $\left(U_{47,23}=368.5\right.$, $p=0.03)$ and odd-numbered alkanes $\left(U_{47,23}=195.5\right.$, $p=0.000$ ) in the samples of beeswax obtained from light and dark coloured combs. Statistically significant differences were also found for the content of some alkanes, as follows: $\mathrm{C}_{23} \mathrm{H}_{48}\left(\mathrm{U}_{47,23}=210.5\right.$, $p=0.000), C_{25} H_{52}\left(U_{47.23}=212.0, p=0.000\right), C_{27} H_{56}$ $\left(U_{47,23}=334.0, p=0.01\right), C_{28} H_{58}\left(U_{47,23}=373.5\right.$, $\mathrm{p}=0.03), \mathrm{C}_{30} \mathrm{H}_{62}\left(\mathrm{U}_{47.23}=185.0, \mathrm{p}=0.000\right)$, and $\mathrm{C}_{32} \mathrm{H}_{66}\left(\mathrm{U}_{47,23}=145.5, \mathrm{p}=0.000\right)$ (Tab. 1). Furthermore, samples of the virgin beeswax showed the highest variability ( $C V=40.6 \%)$ for the content of $\mathrm{C}_{32} \mathrm{H}_{66}$ and for alkanes of the homologous series from $\mathrm{C}_{20} \mathrm{H}_{42}$ to $\mathrm{C}_{24} \mathrm{H}_{50}$ (CV from 30.8 to $35.2 \%$ ). In the case of the beeswax obtained from dark combs, the highest variability (CV from 48.1 to $53.7 \%$ ) was found for the content of n-alkanes from $\mathrm{C}_{20} \mathrm{H}_{42}$ to $\mathrm{C}_{22} \mathrm{H}_{46}$ and for $\mathrm{C}_{24} \mathrm{H}_{50}(\mathrm{CV}=43.3 \%)$ and $\mathrm{C}_{32} \mathrm{H}_{66}$ (CV $=44.1 \%)$. The lowest variability (CV from 6.0 to $13.2 \%$ ) was found for the beeswax samples obtained from light and from dark coloured combs in relation to the content of $\mathrm{C}_{29} \mathrm{H}_{60^{\prime}} \mathrm{C}_{31} \mathrm{H}_{64^{\prime}}$ and $\mathrm{C}_{27} \mathrm{H}_{56}$.

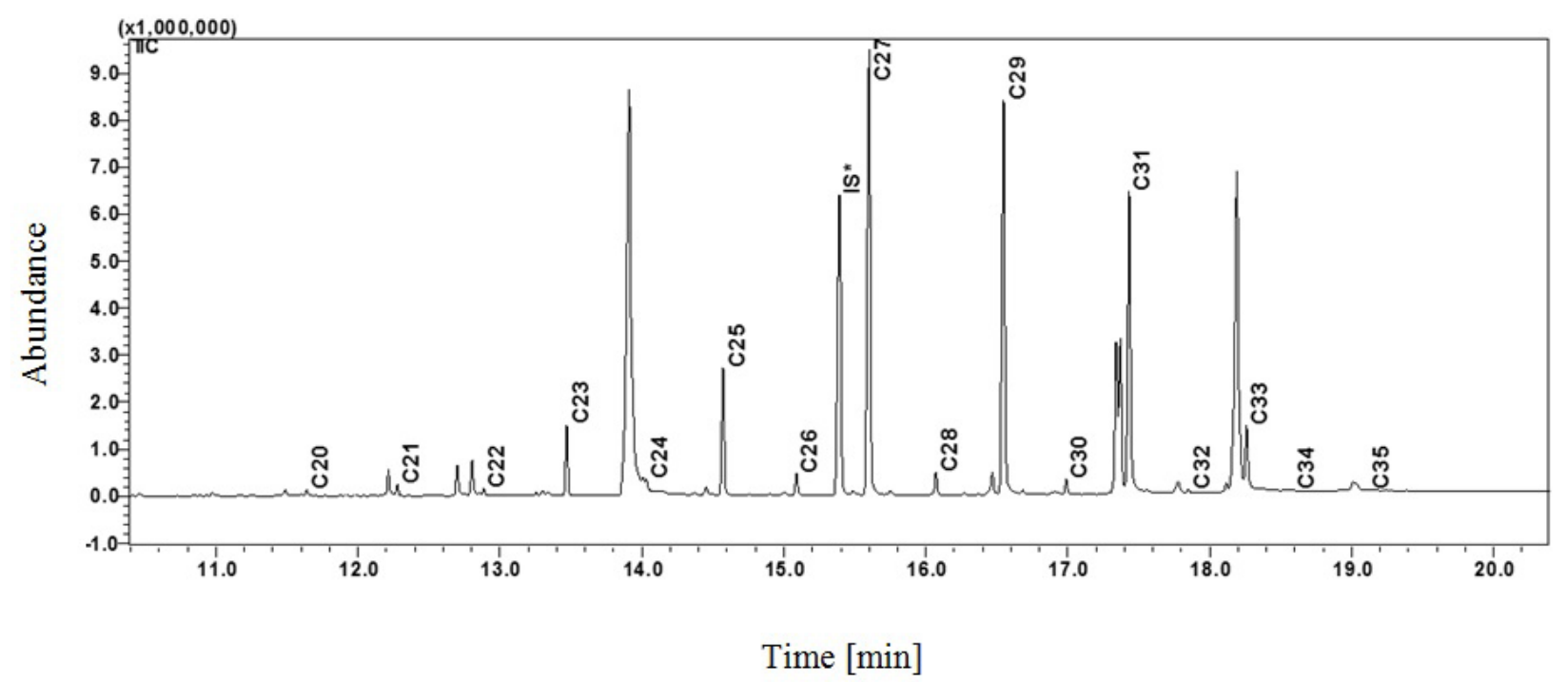

Fig. 1. Chromatogram of hydrocarbons in beeswax collected from light coloured comb (C2O - C35 - n-alkanes $\mathrm{C}_{20} \mathrm{H}_{42}-\mathrm{C}_{35} \mathrm{H}_{72} ;$ i $\mathrm{S}^{*}$ - Internal Standard). 
Table 1.

Contents of n-alkanes (g/100 g) determined in beeswax collected from light and dark combs

\begin{tabular}{|c|c|c|c|c|c|c|}
\hline \multirow{2}{*}{$\begin{array}{l}\text { Formula of } \\
\text { n-alkane }\end{array}$} & \multicolumn{3}{|c|}{ Light combs $(n=47)$} & \multicolumn{3}{|c|}{ Dark combs $(n=23)$} \\
\hline & Min - Max & Mean \pm SD & CV (\%) & Min - Max & Mean \pm SD & CV (\%) \\
\hline $\mathrm{C}_{20} \mathrm{H}_{42}$ & $0.02-0.05$ & 0.01 & 32.5 & $0.01-0.06$ & 0.01 & 53.7 \\
\hline $\mathrm{C}_{21} \mathrm{H}_{44}$ & $0.03-0.08$ & 0.02 & 30.8 & $0.03-0.10$ & $=0.02$ & 48.1 \\
\hline $\mathrm{C}_{22} \mathrm{H}_{46}$ & $0.02-0.06$ & .01 & 31.6 & 0.09 & 0.02 & 52.2 \\
\hline $\mathrm{C}_{23} \mathrm{H}_{48}$ & $12-0.56$ & .11 & 35.2 & 0.68 & 0.12 & 26.2 \\
\hline $\mathrm{C}_{24} \mathrm{H}_{50}$ & $0.03-0.12$ & 0.02 & 33.9 & $0.04-0.13$ & 0.03 & 43.3 \\
\hline $\mathrm{C}_{25} \mathrm{H}_{52}$ & $0.42-1.47$ & 0.82 & 22.7 & 1.37 & 0.18 & 18.0 \\
\hline $\mathrm{C}_{26} \mathrm{H}_{54}$ & $0.06-0.18$ & $0.12 \mathrm{a}$ & 19.1 & $0.09-0.22$ & $0.13 a \pm 0.05$ & 34.4 \\
\hline $\mathrm{C}_{27} \mathrm{H}_{56}$ & $2.44-4.40$ & $3.23 b \pm 0.43$ & 13.2 & $2.78-4.17$ & $3.03 a \pm 0.44$ & 12.6 \\
\hline $\mathrm{C}_{28} \mathrm{H}_{58}$ & $0.06-0.14$ & $0.10 a \pm 0.02$ & 20.2 & $0.08-0.19$ & $0.12 b \pm 0.04$ & 29.6 \\
\hline $\mathrm{C}_{29} \mathrm{H}_{60}$ & $1.68-2.73$ & $2.23 a \pm 0.22$ & 10.1 & $1.96-2.59$ & $2.30 a \pm 0.14$ & 6.0 \\
\hline $\mathrm{C}_{30} \mathrm{H}_{62}$ & $0.05-0.11$ & $0.08 a \pm 0.01$ & 17.8 & $0.06-0.19$ & $0.12 b \pm 0.04$ & 31.9 \\
\hline $\mathrm{C}_{31} \mathrm{H}_{64}$ & $1.53-2.64$ & $1.93 a \pm 0.24$ & 12.6 & $1.69-2.25$ & $1.88 a \pm 0.12$ & 6.3 \\
\hline $\mathrm{C}_{32} \mathrm{H}_{66}$ & $0.01-0.07$ & $0.03 a \pm 0.01$ & 40.6 & $0.02-0.12$ & $0.07 b \pm 0.03$ & 44.1 \\
\hline $\mathrm{C}_{33} \mathrm{H}_{68}$ & $0.31-0.67$ & $0.45 a \pm 0.10$ & 21.5 & $0.24-0.76$ & $0.38 a \pm 0.15$ & 38.7 \\
\hline $\mathrm{C}_{34} \mathrm{H}_{70}$ & $<0.025^{\star \star}-0.03$ & - & - & $<0.025^{\star \star}-0.03$ & - & - \\
\hline $\mathrm{C}_{35} \mathrm{H}_{72}$ & $<0.025^{\star \star}-0.03$ & - & - & $<0.025^{\star \star}-0.03$ & - & - \\
\hline $\begin{array}{c}\text { Total } \\
\mathrm{C}_{20} \mathrm{H}_{42}-\mathrm{C}_{35} \mathrm{H}_{72}\end{array}$ & $27-11.66$ & $9.50 a \pm 0.72$ & 7.6 & 9.46 - 10.84 & $10.22 b \pm 0.36$ & 3.5 \\
\hline $\begin{array}{c}\text { Total of even } \\
\text { n-alkanes }\end{array}$ & .64 & $0.47 a \pm c$ & 17.5 & 99 & $0.59 b \pm 0.20$ & 34 \\
\hline $\begin{array}{r}\text { Total of } \\
\text { n-alkar }\end{array}$ & - 11.18 & 59 & 7.7 & 35 & $9.63 \mathrm{~b} \pm$ & 3. \\
\hline
\end{tabular}

${ }^{*} \mathrm{a}, \mathrm{b}$ - indicate significant differences between means (Mann-Whitney $\mathrm{U}$ test, $\mathrm{p} \leq 0.05$ )

* limit of determination

The total content of n-alkanes in the virgin beeswax samples collected in 2009 was from 8.27 to $11.66 \mathrm{~g} / 100 \mathrm{~g}$ (on average, $9.55 \mathrm{~g} / 100 \mathrm{~g}$ ), with CV $9.6 \%$ (Tab. 2). Similar results were obtained for the total content of all unbranchedalkanes in the beeswax collected in 2010: from 8.46 to $10.72 \mathrm{~g} / 100 \mathrm{~g}$ (on average, $9.47 \mathrm{~g} / 100 \mathrm{~g}$ ), but the results were characterised by a slightly lower variability (CV $=6.4 \%$ ). The average total contents of even- and odd-numbered alkanes for samples collected in 2009 were 0.41 and $9.14 \mathrm{~g} / 100 \mathrm{~g}$, respectively. In the case of the virgin beeswax samples collected in 2010, the average content of even-numbered alkanes was slightly higher and amounted to $0.51 \mathrm{~g} / 100 \mathrm{~g}$, and the average content of odd-numbered alkanes was lower and amounted to $8.96 \mathrm{~g} / 100 \mathrm{~g}$. However, statistically significant differences were found only for the total content of alkanes with an even number of carbon atoms in the molecule $\left(U_{16,31}=68.5\right.$, $p=0.000)$, and for the content of the majority of individual alkanes: $\mathrm{C}_{20} \mathrm{H}_{42}\left(\mathrm{U}_{16,31}=36.0, \mathrm{p}=0.000\right)$, $\mathrm{C}_{21} \mathrm{H}_{44}\left(\mathrm{U}_{16,31}=43.0, \mathrm{p}=0.000\right), \mathrm{C}_{22} \mathrm{H}_{46}\left(\mathrm{U}_{16,31}\right.$ $=60.0, \mathrm{p}=0.000), \mathrm{C}_{23} \mathrm{H}_{48}\left(\mathrm{U}_{16,31}=16.0, \mathrm{p}=0.000\right)$, $\mathrm{C}_{24} \mathrm{H}_{50}\left(\mathrm{U}_{16,31}=29.0, \mathrm{p}=0.000\right), \mathrm{C}_{26} \mathrm{H}_{54}\left(\mathrm{U}_{16,31}=76.0\right.$, $p=0.000), C_{27} H_{56}\left(U_{16,31}=73.0, p=0.000\right), C_{28} H_{58}$ $\left(U_{16,31}=49.5, p=0.000\right)$, and $C_{32} H_{66}\left(U_{16,31}=73.5\right.$, $p=0.000$ ).

The total content of n-alkanes in beeswax collected at different periods during 2010 was similar and ranged from 8.46 to $10.33 \mathrm{~g} / 100 \mathrm{~g}$; on average, $9.39 \mathrm{~g} / 100 \mathrm{~g}$ (for the samples collected in May and June), and from 8.69 to $10.72 \mathrm{~g} / 100 \mathrm{~g}$; on average, $9.60 \mathrm{~g} / 100 \mathrm{~g}$ (for samples collected in July). The samples of virgin beeswax collected in different periods of 2010 showed similar variability (Tab. 3). The contents of individual unbranched 
Contents of n-alkanes $(\mathrm{g} / 100 \mathrm{~g})$ determined

Table 2. in virgin beeswax collected in 2009 and 2010

\begin{tabular}{|c|c|c|c|c|c|c|}
\hline \multirow{2}{*}{$\begin{array}{l}\text { Formula of } \\
\text { n-alkane }\end{array}$} & \multicolumn{3}{|c|}{$2009(n=16)$} & \multicolumn{3}{|c|}{$2010(n=31)$} \\
\hline & Min - Max & Mean \pm SD & CV (\%) & Min - Max & Mean \pm SD & CV (\%) \\
\hline $\mathrm{C}_{20} \mathrm{H}_{42}$ & $0.02-0.04$ & $0.02 a^{*} \pm 0.01$ & 28.3 & $0.02-0.05$ & $0.04 b^{*} \pm 0.01$ & 21.9 \\
\hline $\mathrm{C}_{21} \mathrm{H}_{44}$ & $0.03-0.08$ & $0.04 a \pm 0.01$ & 33.6 & $0.03-0.08$ & $0.06 b \pm 0.01$ & 17.7 \\
\hline $\mathrm{C}_{22} \mathrm{H}_{46}$ & $0.02-0.06$ & $0.03 a \pm 0.01$ & 40.2 & $0.02-0.06$ & $0.04 b \pm 0.01$ & 21.0 \\
\hline $\mathrm{C}_{23} \mathrm{H}_{48}$ & $0.12-0.30$ & $0.19 a \pm 0.05$ & 26.0 & $0.19-0.56$ & $0.36 b \pm 0.08$ & 22.0 \\
\hline $\mathrm{C}_{24} \mathrm{H}_{50}$ & $0.03-0.10$ & $0.05 a \pm 0.02$ & 36.1 & $0.05-0.12$ & $0.09 b \pm 0.01$ & 15.6 \\
\hline $\mathrm{C}_{25} \mathrm{H}_{52}$ & $0.52-1.47$ & $0.80 a \pm 0.25$ & 31.6 & $0.42-1.13$ & $0.83 a \pm 0.15$ & 17.9 \\
\hline $\mathrm{C}_{26} \mathrm{H}_{54}$ & $0.06-0.18$ & $0.10 a \pm 0.03$ & 26.4 & $0.08-0.15$ & $0.13 b \pm 0.02$ & 12.1 \\
\hline $\mathrm{C}_{27} \mathrm{H}_{56}$ & $2.90-4.40$ & $3.58 \mathrm{~b} \pm 0.39$ & 11.0 & $2.44-3.53$ & $3.05 a \pm 0.32$ & 10.5 \\
\hline $\mathrm{C}_{28} \mathrm{H}_{58}$ & $0.06-0.12$ & $0.08 a \pm 0.02$ & 20.5 & $0.07-0.14$ & $0.11 b \pm 0.01$ & 12.3 \\
\hline $\mathrm{C}_{29} \mathrm{H}_{60}$ & $1.68-2.70$ & $2.15 a \pm 0.26$ & 12.0 & $1.88-2.73$ & $2.28 a \pm 0.19$ & 8.6 \\
\hline $\mathrm{C}_{30} \mathrm{H}_{62}$ & $0.05-0.11$ & $0.08 a \pm 0.02$ & 23.1 & $0.05-0.11$ & $0.08 a \pm 0.01$ & 14.8 \\
\hline $\mathrm{C}_{31} \mathrm{H}_{64}$ & $1.53-2.64$ & $1.93 a \pm 0.28$ & 14.4 & $1.55-2.46$ & $1.94 a \pm 0.23$ & 11.8 \\
\hline $\mathrm{C}_{32} \mathrm{H}_{66}$ & $0.01-0.07$ & $0.04 b \pm 0.01$ & 35.6 & $0.02-0.04$ & $0.03 a \pm 0.01$ & 23.2 \\
\hline $\mathrm{C}_{33} \mathrm{H}_{68}$ & $0.31-0.67$ & $0.45 a \pm 0.10$ & 22.1 & $0.31-0.66$ & $0.44 a \pm 0.10$ & 21.5 \\
\hline $\mathrm{C}_{34} \mathrm{H}_{70}$ & $<0.025^{* \star}-0.03$ & - & - & $<0.025^{* *}-0.03$ & - & - \\
\hline $\mathrm{C}_{35} \mathrm{H}_{72}$ & $<0.025^{\star *}-0.03$ & - & - & $<0.025^{* *}-0.03$ & - & - \\
\hline $\begin{array}{c}\text { Total } \\
\mathrm{C}_{20} \mathrm{H}_{42}-\mathrm{C}_{35} \mathrm{H}_{72} \\
\end{array}$ & $8.27-11.66$ & $9.55 a \pm 0.92$ & 9.6 & $8.46-10.72$ & $9.47 a \pm 0.61$ & 6.4 \\
\hline $\begin{array}{c}\text { Total of even } \\
\text { n-alkanes }\end{array}$ & $0.26-0.64$ & $0.41 a \pm 0.09$ & 23.0 & $0.36-0.56$ & $0.51 b \pm 0.05$ & 10.1 \\
\hline $\begin{array}{c}\text { Total of odd } \\
\text { n-alkanes }\end{array}$ & $8.01-11.18$ & $9.14 a \pm 0.88$ & 9.6 & $8.00-10.16$ & $8.96 a \pm 0.58$ & 6.5 \\
\hline
\end{tabular}

${ }^{*} \mathrm{a}, \mathrm{b}$ - indicate significant differences between means (Man-Whitney $U$ test, $\mathrm{p} \leq 0.05$ )

** limit of determination

alkanes determined in samples of beeswax collected at different dates of the same beekeeping season, were similar. Statistically significant differences for the total content of n-alkanes, and for the content of individual alkanes in samples of beeswax collected at different periods of 2010, were not found. The contents of n-alkanes varied the highest in respect to the content of $\mathrm{C}_{20} \mathrm{H}_{42}-\mathrm{C}_{22} \mathrm{H}_{46}$ for samples collected in May-June (CV from 20.8 to $24.9 \%$ ), and $\mathrm{C}_{23} \mathrm{H}_{48}$ and $\mathrm{C}_{32} \mathrm{H}_{66}-\mathrm{C}_{33} \mathrm{H}_{68}$ for samples collected in July (CV from 24.5 to $29.6 \%$ ). The contents varied the lowest in respect to the content of $\mathrm{C}_{29} \mathrm{H}_{60}$ for samples from May - June ( $C V=6.2 \%)$, and $\mathrm{C}_{26} \mathrm{H}_{54}(\mathrm{CV}=8.4 \%)$ and $\mathrm{C}_{27} \mathrm{H}_{56}$ (CV $=9.1 \%$ ) for samples collected in July (Tab. 3).

\section{DISCUSSION}

Qualitative analysis did not show differences in the hydrocarbon composition of beeswax (Apis mellifera) collected from light and dark coloured combs. In the virgin beeswax and the beeswax obtained from brood combs the same hydrocarbons (n-alkanes, alkenes, and dienes) were identified. The dominant group of the beeswax hydrocarbons is unbranched alkanes containing from 20 to 35 carbon atoms. These results are in line with those reported by other authors (White et al., 1960; Downing et al.,1961; Aichholz and Lorbeer, 1999, 2000; Jimenez et al., 2004; Serra Bonvehi and Ornantes Bermejo, 2012; Maia and Nunes, 2013; Waś et al., 2014). In addition, our studies showed differences in the content of n-alkanes in the beeswax collected from light and dark combs. In comparison to the virgin 
Table 3.

Contents of n-alkanes (g/100 g) determined in virgin beeswax collected in different periods of 2010

\begin{tabular}{|c|c|c|c|c|c|c|}
\hline \multirow{2}{*}{$\begin{array}{c}\text { Formula of } \\
\text { n-alkane }\end{array}$} & \multicolumn{3}{|c|}{ May - June $(n=20)$} & \multicolumn{3}{|c|}{ July $(n=11)$} \\
\hline & Min - Max & Mean $^{*} \pm$ SD & CV (\%) & Min - Max & Mean $^{*} \pm$ SD & $\overline{C V}(\%)$ \\
\hline $\mathrm{C}_{20} \mathrm{H}_{42}$ & $0.02-0.05$ & $0.04 \pm 0.01$ & 24.9 & $0.03-0.05$ & $0.04 \pm 0.01$ & 16.6 \\
\hline $\mathrm{C}_{21} \mathrm{H}_{44}$ & $0.03-0.08$ & $0.06 \pm 0.01$ & 20.8 & $0.06-0.08$ & $0.06 \pm 0.01$ & 11.1 \\
\hline $\mathrm{C}_{22} \mathrm{H}_{46}$ & $0.02-0.06$ & $0.04 \pm 0.01$ & 23.0 & $0.03-0.05$ & $0.04 \pm 0.01$ & 17.7 \\
\hline $\mathrm{C}_{23} \mathrm{H}_{48}$ & $0.19-0.45$ & $0.36 \pm 0.06$ & 17.5 & $0.23-0.56$ & $0.40 \pm 0.10$ & 24.5 \\
\hline $\mathrm{C}_{24} \mathrm{H}_{50}$ & $0.05-0.10$ & $0.08 \pm 0.01$ & 16.7 & $0.08-0.12$ & $0.09 \pm 0.01$ & 12.3 \\
\hline $\mathrm{C}_{25} \mathrm{H}_{52}$ & $0.42-1.00$ & $0.81 \pm 0.16$ & 19.3 & $0.72-1.13$ & $0.87 \pm 0.13$ & 15.1 \\
\hline $\mathrm{C}_{26} \mathrm{H}_{54}$ & $0.08-0.15$ & $0.12 \pm 0.02$ & 13.8 & $0.11-0.15$ & $0.13 \pm 0.01$ & 8.4 \\
\hline $\mathrm{C}_{27} \mathrm{H}_{56}$ & $2.44-3.52$ & $3.01 \pm 0.34$ & 11.3 & $2.64-3.53$ & $3.11 \pm 0.28$ & 9.1 \\
\hline $\mathrm{C}_{28} \mathrm{H}_{58}$ & $0.09-0.14$ & $0.11 \pm 0.01$ & 10.6 & $0.07-0.14$ & $0.11 \pm 0.02$ & 15.5 \\
\hline $\mathrm{C}_{29} \mathrm{H}_{60}$ & $2.02-2.68$ & $2.26 \pm 0.14$ & 6.2 & $1.88-2.73$ & $2.30 \pm 0.28$ & 12.0 \\
\hline $\mathrm{C}_{30} \mathrm{H}_{62}$ & $0.06-0.10$ & $0.08 \pm 0.01$ & 12.0 & $0.05-0.11$ & $0.08 \pm 0.02$ & 19.6 \\
\hline $\mathrm{C}_{31} \mathrm{H}_{64}$ & $1.67-2.42$ & $1.95 \pm 0.21$ & 10.6 & $1.55-2.46$ & $1.91 \pm 0.28$ & 14.4 \\
\hline $\mathrm{C}_{32} \mathrm{H}_{66}$ & $0.02-0.04$ & $0.03 \pm 0.01$ & 19.6 & $0.02-0.04$ & $0.03 \pm 0.01$ & 29.6 \\
\hline $\mathrm{C}_{33} \mathrm{H}_{68}$ & $0.33-0.63$ & $0.45 \pm 0.09$ & 19.6 & $0.31-0.66$ & $0.43 \pm 0.11$ & 25.6 \\
\hline $\mathrm{C}_{34} \mathrm{H}_{70}$ & $<0.025^{* *}-0.03$ & - & - & $<0.025^{* *}-0.03$ & - & - \\
\hline $\mathrm{C}_{35} \mathrm{H}_{72}$ & $<0.025^{\star \star}-0.03$ & - & - & $<0.025^{\star \star}-0.03$ & - & - \\
\hline $\begin{array}{c}\text { Total } \\
\mathrm{C}_{20} \mathrm{H}_{42}-\mathrm{C}_{35} \mathrm{H}_{72}\end{array}$ & 8.46 - 10.33 & $9.39 \pm 0.57$ & 6.0 & $8.69-10.72$ & $9.60 \pm 0.68$ & 7.1 \\
\hline $\begin{array}{c}\text { Total of even } \\
\text { n-alkanes }\end{array}$ & $0.36-0.56$ & $0.50 \pm 0.05$ & 10.2 & $0.41-0.56$ & $0.50 \pm 0.05$ & 9.8 \\
\hline $\begin{array}{c}\text { Total of odd } \\
\text { n-alkanes }\end{array}$ & $8.0-9.78$ & $8.89 \pm 0.54$ & 6.1 & $8.24-10.16$ & $9.09 \pm 0.65$ & 7.2 \\
\hline
\end{tabular}

* Mann-Whitney $U$ test for comparing of $n$-alkanes (g/100 g) determined in beeswax collected in different periods of 2010, $p \leq 0.05$

${ }^{* \star}$ limit of determination

beeswax, the beeswax obtained from dark combs had a higher content of the total n-alkanes, the total contents of even- and odd-numbered alkanes, and contents of certain alkanes. The maximum values of the contents of some n-alkanes $\left(\mathrm{C}_{25} \mathrm{H}_{52^{\prime}}\right.$ $\mathrm{C}_{27} \mathrm{H}_{56^{\prime}}, \mathrm{C}_{29} \mathrm{H}_{60^{\prime}} \mathrm{C}_{31} \mathrm{H}_{64}$ ) and the total of all n-alkanes were determined in the beeswax obtained from light combs. Additionally, it was found that in the beeswax originating from light and dark coloured combs the content of odd-numbered unbranched alkanes was substantially higher in comparison to the content of the even-numbered alkanes. The content of even-numbered alkanes was slightly higher and amounted to $5.8 \%$ in the samples of the beeswax from dark combs, while in the virgin beeswax was $5.1 \%$. Higher contents of even-numbered alkanes in the beeswax obtained from dark combs in comparison to the content of these alkanes in the virgin beeswax were also indicated by Jimenez et al. (2007), and Namdar et al. (2007). The higher contents of hydrocarbons in the beeswax obtained from dark combs confirm previous results reported by Curyło and Zalewski (1957), and also by Tulloch and Hoffman (1972). It is important to note, that, the contents determined by these authors were higher than our results because they were related to the total of all hydrocarbons occurring in beeswax, while in our work only one group (n-alkanes) was analysed quantitatively. The contents of the total unbranched alkanes and of individual n-alkanes determined by us 


\section{Ј. APPC. SCL. VOL. 58 N NO. 22014}

were lower in comparison to the contents assessed by other authors (Aichholz and Lorbeer, 1999, 2000; Jimenez et al., 2004, 2006, 2007; Serra Bonvehi and Ornantes Bermejo, 2012; Maia and Nunes, 2013). The discrepancy of the results obtained by different researchers for the quantitative analysis of the beeswax hydrocarbons were mentioned in our previous report (Waś et al., 2014).

In order to characterise the beeswax more precisely, the composition of the virgin beeswax collected in different years and at different periods of the same year were also compared in the current studies. In the beeswax collected in 2009 and 2010 from light combs, no differences in the qualitative composition were found, and the results obtained for the total of all the unbranched alkanes were also similar. Statistically significant differences were found only for even-numbered alkanes and for the contents of some alkanes (from $\mathrm{C}_{20} \mathrm{H}_{42}$ to $\mathrm{C}_{24} \mathrm{H}_{50}$ from $\mathrm{C}_{26} \mathrm{H}_{54}$ to $\mathrm{C}_{28} \mathrm{H}_{58}$ and also $\mathrm{C}_{32} \mathrm{H}_{66}$ ). The differences could have resulted from the different numbers of samples. In 2010, the number of analysed samples was 31 and all originated from the cooperating apiary, in which the majority of colonies belonged to the Caucasian race. In 2009, substantially fewer samples were analysed $(n=16)$. The majority of the samples $(n=10)$ originated from the apiaries of the Department of Beekeeping Technology, the Apiculture Division, from the colonies of Caucasian and Carniolan honey bees. It is possible that the observed differences in the content of n-alkanes were also a result of the fact that the beeswax originated from different honey bee races. Differences in the quantitative composition (e.g., hydrocarbons) of the beeswax obtained from different species and races were shown by Brand-Garnys and Sprenger (1988), and Aichholz and Lorbeer (1999, 2000). However, no literature data are available on the composition of beeswax secreted by honey bees of the Caucasian or Carniolan race. Only the difference in the production capacity of these races were found. The Caucasian honey bees produced more beeswax in comparison to honey bees of the Carniolan race (Skowronek, 1976). Furthermore, studies by Skowronek (1976) and Skowronek et al. (1978) proved that the production of beeswax is strictly related to flow conditions. There were worse flow conditions and honey production was lower in 2010. In the cooperating apiary in 2010, the honey obtained (on average, about $20 \mathrm{~kg}$ of honey from one colony) was twice as low in comparison to the honey obtained in 2009. There is no information available in the literature on whether and in what way the flow conditions influence the beeswax composition.
In the latter part of the study, an analysis was done of virgin beeswax collected at different periods in the same year. All the samples originated from the cooperating apiary. The total content of unbranched n-alkanes in beeswax collected at different dates, was similar. Statistically significant differences for the total content of n-alkanes as well as for the content of individual alkanes in samples of beeswax collected at different periods of 2010, were not found. The presented results cannot be compared to other authors' previous results because no report published so far takes into consideration the collection date of the samples.

\section{CONCLUSIONS}

The qualitative hydrocarbon composition of beeswax obtained from light and dark coloured combs is the same, but the beeswax obtained from dark combs contains more unbranched alkanes (n-alkanes) in comparison to the virgin beeswax. Furthermore, current studies indicate that qualitative and quantitative hydrocarbon composition of beeswax does not depend on the collection period.

\section{ACKNOWLEDGMENTS}

The authors are grateful to the individual beekeeper, as well as colleagues from the Department of Beekeeping Technology of Apiculture Division, Research Institute of Horticulture for supplying the beeswax samples.

This research was supported in part by the Ministry of Science and Higher Education of Poland, COST ACTIONFA0803, grant number 527/N-COST/2009/0.

\section{REFERENCES}

Aichholz R., Lorbeer E. (1999) Investigation of combwax of honeybees with high-temperature gas chromatography and high-temperature gas chromatography-chemical ionization mass spectrometry. I - High-temperature gas chromatography. Journal of Chromatography A 855: 601-615. DOl: 10.1016/S0021-9673(99)00725-6

Aichholz R., Lorbeer E. (2000) Investigation of combwax of honeybees with high-temperature gas chromatography and high-temperature gas chromatography-chemical ionization mass spectrometry. II - High-temperature gas chromatography-chemical ionization mass spectrometry. Journal of Chromatography A 883: 75-88. D0l: 10.1016/S0021-9673(00)00386-1 
Beverly M. B., Kay P. T., Voorhees K. J. (1995) Principal component analysis of the pyrolysis - mass spectra from African, Africanized hybrid and European beeswax. Journal of Analytical and Applied Pyrolysis 34: 251-263.

Brand-Garnys E. E., Sprenger J. (1988) Bienenwachs Neue Aspekte eines klassischen Kosmetic - Rohstoffes. Z. Körperpflegemittel-, Parfümerie-, Riechstoff- und Aerosol - Industrie 61 (14): 547-552.

Carlson D. A., Bolton A. B. (1984) Identification of Africanized and European bees using extracted hydrocarbons. Bulletin of the Entomological Society of America 30: 32-35.

Curyło J., Zalewski W. (1957) Charakterystyka krajowego wosku pszczelego z naturalnych nieczerwionych plastrów oraz charakterystyka węglowodorów wydzielonych z niego przy pomocy chromatografii. Pszczelnicze Zeszyty Naukowe 1(3): 105-117.

Downing T. D, Kranz Z. H, Lamberton J. A., Murray K. E., Redcliffe A. H. (1961) Studies in waxes. XVIII. Beeswax: A spectroscopic and gas chromatographic examination. Australian Journal of Chemistry 14: 253-263.

Giumanini A. G., Verardo G., Strazzolini P., Hepburn H. R. (1995) Rapid detection of high-molecular-mass dienes in beeswax. Journal of Chromatography A 704: 224-227. DOl: 10.1016/0021-9673(95)00145-D

Jimenez J. J., Bernal J. L., Aumente S., del Nozal M. J., Martin M. T., Bernal Jr. J. (2004) Quality assurance of commercial beeswax - Part I. Gas chromatography - electron impact ionization mass spectrometry of hydrocarbons and monoesters. Journal of Chromatography A 1024: 147154. DOI: 10.1016/j.chroma.2003.10.063

Jimenez J. J., Bernal J. L., del Nozal M. J., Martin M. T., Bernal J. (2006) Sample preparation methods for beeswax characterization by gas chromatography with flame ionization. Journal of Chromatography A 1129: 262-272. DOl: 10.1016/j.chroma.2006.06.098

Jimenez J. J., Bernal J. L., del Nozal M. J., Toribio L., Bernal J. (2007) Detection of beeswax adulterations using concentration guide-values. European Journal of Lipid Science and Technology 109: 682-690. D0l: 10.1002/ ejlt.200600308
Maia M., Nunes F. M. (2013) Authentication of beeswax (Apis mellifera) by high-temperature gas chromatography and chemometric analysis. Food Chemistry 136: 961-968. DOl: 10.1016/j.foodchem.2012.09.003

Namdar D., Neuman R., Sladezki Y., Haddad N., Weiner S. (2007) Alkane composition variations between darker and lighter colored comb beeswax. Apidologie 38: 453461. DOI: 10.1051/apido:2007033

Serra Bonvehi J., Ornantes Bermejo F. J. (2012) Detection of adulterated commercial Spanish beeswax. Food Chemistry 132: 642-648. D0l: 10.1016/j.foodchem.201 1.10.104

Skowronek W. (1976) Możliwości produkcyjne wosku i budowa plastrów przez pszczoły trzech ras. Pszczelnicze Zeszyty Naukowe 20: 85-95.

Skowronek W., Bornus L., Bobrzecki j., Cieśla L., Gromisz M., Kaczmarek S., Kalinowski J., Król A., Nowakowski J., Woźnica J., Zaremba J. (1978) Badania nad międzyliniowymi mieszańcami pszczoły miodnej. III. Produkcja wosku w różnych warunkach pożytkowych. Pszczelnicze Zeszyty Naukowe 22: 31-38.

\section{Statistica v. 10 (201 1) StatSoft Inc.}

Streibl M., Stransky K., Sorm F. (1966) Über einige neue Kohlenwasserstoffe in Wachs der Honigbiene (Apis mellifera L.). Fette Seifen Anstrichmittel 68: 799-805.

Tulloch A., Hoffman L. L. (1972) Canadian Beeswax: Analytical Values and Composition of Hydrocarbons, Free Acids and Long Chain Esters. Journal of the American Oil Chemists' Society 49: 696-699.

Waś E., Szczęsna T., Rybak-Chmielewska H. (2014) Determination of beeswax hydrocarbons by gas chromatography with a mass detector (GC-MS) technique. Journal of Apicultural Science 58(1): 145-157. DOI: 10.2478/ JAS-2014-0015

White J. W. Jr., Reader M., K., Riethof M. L. (1960) Chromatographic Determination of Hydrocarbons in Beeswax. Journal of the Association of Official Agricultural Chemists 43: 778-780. 